\title{
The Effect of Military Expenditure on Profit Rates: Evidence from Major Countries
}

Adem Yavuz Elveren ${ }^{a} \quad$ Sara Hsub

Received: 21.10.2018; Revised: 10.11.2018; Accepted: 15.11.2018

This article provides evidence of the effect of military expenditures on the rate of profits by focusing on 32 major countries for the period of 1963-2008 by using data from the Extended Penn World Tables, the University of Texas Inequality Project Estimated Household Income Inequality, the World Development Indicator, and the Stockholm International Peace Research Institute. The article employs a Generalized Method of Moment model within a Marxist framework. Findings show that military expenditures have positive effect on the rate of profits. It is also showed that increasing income inequality increases the rate of profits. Finally, the findings suggest that while military expenditures have a positive effect on the profit rates in the case of both armsexporting countries and net-arms exporters, the relationship is not that significant in the case of arms-importing countries.

JEL codes: C33, E11, H50

Keywords: Military expenditure, Profit rate, Income inequality, Panel data, Marxist economics

\section{Introduction}

This paper examines if military expenditures (milex henceforth) counteract the tendency for the profit rate to decline. Increasing milex may have both positive and negative effects on the profit rates as noted in the Marxist literature. A rise in spending results in an increase in aggregate demand, avoids a profit-reducing rise in the organic composition of capital, and improves the rate of surplus value by boosting labor productivity. At the same time, however, increasing milex can result in crowding out of private investment and a reduction in profitability resulting from the purchase of "unproductive" goods. This can further negatively impact the profit rate through increasing the organic composition of capital and taxing capital income (Kollias \& Maniatis, 2003; Elveren \& Hsu, 2016).

Although there have been sizeable studies on the tendency for the profit rate to decline in the Marxist literature (Duménil \& Lévy, 2011; Basu \& Vasudevan, 2013), and on the effect of milex on economic growth in the defence and peace economics literature (Dunne \& Uye, 2010; Alptekin \& Levine, 2012), there are very few works that deal with the effect of milex on the profit rate. Therefore, this study provides some evidence on a crucial

a Department of Economics, History, and Political Science, Fitchburg State University, Massachusetts, United States. e-mail: aelveren@fitchburgstate.edu

b Department of Economics, State University of New York-New Paltz, New Paltz, NYE. e-mail: hsus@newpaltz.edu 
relationship between milex and profit rates, which has not received much attention from neither literature.

To the best of our knowledge, there are only four time series and a panel studies that investigated this relationship, for the U.S., the U.K., and West Germany (Georgiou, 1992), for Greece (Kollias \& Maniatis, 2003), for the U.S. (Dunne, Pieroni, \& d'Agostino, 2013), for Turkey (Elveren \& Özgür, 2018), and for 24 OECD countries (Elveren \& Hsu, 2016).

The paper differs from Elveren and Hsu (2016) in four main ways. First, we extend the data set by one third by incorporating eight more countries. In fact, these are major countries like Argentina, Germany, China, India, Brazil, South Korea, South Africa, and Mexico. It is important to test the validity of early findings in the case of extended set of countries. Second, this study considers a crucial variable, income inequality, which has not received much attention in the context of effect of milex on the economy (Ali, 2007; Töngür \& Elveren, 2017). In fact, there is a tri-directional relationship between inequality, milex, and profit rates (Taşıran \& Elveren, 2017). Considering this fact and the sparse coverage of inequality data based on the Gini coefficient, this study utilizes an extensive data set of income inequality, the Estimated Household Income Inequality data set, provided by the University of Texas Inequality Project. Third, we improve the dummy variables to better test the difference between arms-exporting and arms-importing countries, one of the major findings in Elveren and Hsu (2016). Finally, we employ a few different estimation methods, as part of our robustness analysis, providing evidence regarding the causality between milex and profit rates.

This paper examines the effect of milex on profit rates for 32 major countries for the period of 1963-2008 by using a Generalized Method of Moment (GMM) estimation. Our results support and strengthen the earlier findings by revealing differing effects of milex on the profit rate with respect to the roles of countries in the arms trade. In the next section, we provide a background on the Marxian literature's debate on the effect of milex on profitability. In Section 3, we introduce the data as well as the empirical model. Section 4 discusses the results of this analysis. The last section summarizes the findings.

\section{Literature Survey: The Effect of Military Expenditures on Profit Rates}

\subsection{Theoretical Background}

Within the Marxist literature, milex is thought to impact the profit rate via capital productivity as well as through the organic composition of capital. Milex therefore plays a conflicting role in the economy, as has been discussed extensively in the Marxian literature (see inter alia Georgiou (1983); Kollias and Maniatis (2003); Coulomb (2004); Dunne et al. (2013); Elveren and Hsu (2016)) ${ }^{1}$. Although a Marxist theory of militarism has not been developed, Marxist scholars do discuss linkages between milex and the profit rate. These may include any of the following three: Milex can reduce the increase in organic composition of capital and, at the same time, reduce the value of constant capital in the military sector by including surplus that is realized as a profit or removing capital from the non-military sector. Milex may also change the class structure by increasing the exploitation of workers, increasing profit rates (Smith, 1977, 1983).

\footnotetext{
${ }^{1}$ Section 2 is a revised version of discussion in Elveren and Hsu (2016).
} 
There are four approaches to analyzing the role of milex in a capitalist economy, including those of i) Marx and Engels, ii) Rosa Luxemburg, iii) the underconsumptionists, particularly Baran and Sweezy, and (iv) critiques of underconsumptionists (Georgiou, 1983).

Marx and Engels wrote during a time of revolts, in which civilian and military conflicts took place (Coulomb, 2004). Still neither Marx nor Engels attempted to examine economic aspects of war or conflict from a theoretical perspective. For Marx and Engels, militarism was simply a result of the socio-political structure, but the authors did not discuss the effect of military production on the economy, even though Marx pointed out that this explanation was absent. He might have intended to discuss this in another volume of Capital regarding the role of the State, but he was unable to complete this work. Marx's remarks on war and conflict appeared in his Manifesto of the Communist Party co-authored with Engels (Marx, 1848a), the Discourse on Free Trade (Marx, 1848b), articles, particularly in the Neue Rheinische Zeitung, and relatively more important annotations in his correspondence with Engels, (Coulomb \& Bellais, 2008). In those articles, Marx noted that capitalism has to locate overseas outlets in order to counteract the tendency of profit rates to fall.

It was Engels who examined militarism in an extended manner in Anti-Dühring (Engels, 1877) and Can Europe Disarm? (Engels, 1893). Engels (1877) believed that militarism would bring about its own destruction by forcing states to compete with one another and building up their armies, because although force is with the army and navy, they are, as he noted in the chapter on the theory of force, "devilishly expensive". Engels continued that "[f]orce, however, cannot make any money; at most it can take away money that has already been made, ... money must be provided through the medium of economic production ... [n]othing is more dependent on economic prerequisites than precisely army and navy" (Engels, 1877). Later on, Engels (1893) argued that milex does not have a positive effect on the economy, but on the contrary it increases financial difficulty.

Luxemburg (1913[2015]) analyzed the role of milex in the capitalist economy. In fact, she was the first Marxist thinker who examined this issue explicitly, arguing that milex allows economies to open to external markets, and therefore is key in realizing surplus value. Luxemburg also notes that milex in addition to its direct role in primitive accumulation of capital, "destroys the social organisations of primitive societies so that their means of production may be appropriated" via conquest to build a political, social, and economic hegemony in colonies (Luxemburg, 1913[2015], 454).

Luxemburg states that militarism, "[f]rom the purely economic view of point" is "a preeminent means for the realisation of surplus value; it is in itself a province of accumulation" (Luxemburg, 1913[2015], 454). She argued that social capital can remain stable if taxes on the working class are used to pay government officials and army personnel, resulting in a constant level of demand and profit rate. In addition, if taxes are used to pay for weapons production, this can increase the profit rate, as the indirect tax on the working class reduces wages and boosts profits.

Some scholars have interpreted Luxemburg's theory as an 'underconsumptionist theory' in which milex helps to absorb the surplus that capitalist production system produces without increasing productive capacity. Others view the theory as stating that such spending boosts technological development and reduces internal contradictions of capitalist expansion, thereby increasing capital accumulation (Rowthorn, 1980).

Baran and Sweezy (1966) suggest an under-consumptionist theory, with the idea that through milex, capitalists can obtain higher profit rates and lower levels of competition, 
receiving the economic surplus of the economy. From this perspective, milex is an important component of the monopolistic post-war capitalist system, bringing about greater levels of aggregate demand and absorbing surplus without raising wages or capital. Baran and Sweezy argue that large amounts of milex in the 1940s and 1950s became a key element of the development of American power, helped to preserve monopolistic capitalism, resulting in low levels of unemployment and staving off stagnation. The ability of milex to boost employment declines over time, however, as fewer employees with greater skills are required to maintain the military production. In fact, Baran and Sweezy argue, huge military outlays may even contribute to an increase in unemployment as "military research and development are also applicable to civilian production, where they are quite likely to have the effect of raising productivity and reducing the demand for labor" (Baran \& Sweezy, 1966, 215).

Baran and Sweezy find that milex can harm economic activity, since as arms production becomes more capital intensive, it becomes more difficult to prevent a decline in the profit rate. The reason for this is that high levels of milex result in increased taxation, which dampens economic activity. By contrast, a tax cut due to lower milex can result in a crisis of overproduction.

Baran and Sweezy have been criticized extensively by Georgiou (1983). The first reason is that Baran and Sweezy assume a passive working class, even though the size of economic surplus is contingent upon the state of the class struggle. The second is that Baran and Sweezy use a more general definition of economic surplus, not specific to capitalism, than the Marxist definition. The third reason is that they authors do not specify the method of financing milex, which have differing impacts on the profit rates.

A major restatement of Baran and Sweezy made later by Kidron is the theory of 'the permanent arms economy, which asserts that militarism stabilizes the capitalist system (Kidron, 1970). Kidron considers milex counteracting the threat of over-production. Imperialist policies in neo-colonies work to expand the market and to slow down the fall in the profit rate. Milex also stimulates aggregate demand, helping to keep under-consumption at bay. Finally, military research and development benefits the civil sector through a technological spin-off effect. Kidron argued that since arms are a 'luxury' in the sense that they are neither instruments of production nor means of subsistence, "arms production is the key, and seemingly permanent, offset to the 'tendency of the rate of profit to fall" (Kidron, 1970, 56). However, Kidron, also notes that in the long run "military technology is becoming so specialist as to lose some of its economically stabilizing features" (Kidron, 1970, 64).

(Mandel, 1978) also showed that expenditures on armaments are economically unproductive, since they are neither production nor consumption goods. Milex can therefore be used to reduce excess capital and prevent the decline in the rate of profit by eliminating unproductive capital. Defense firms can obtain a higher profit rate because prices and profits are negotiated between the state and the industry.

The permanent arms economy theory has been challenged by a number of scholars. First, some state that this theory suffers from being ahistorical, as does that of Baran and Sweezy (Purdy (1973), cited in Georgiou (1983)). Kaldor (1977) made the case that milex is in fact unproductive, and that there is an inverse relationship between milex as a percentage of GNP and capital investment as a share of GNP. Kaldor also notes that countries that spend less on military research and development end up spending more on civil research and development.

It has also been argued by Gottheil (1986) that the analyses by Baran and Sweezy 
(1966), Magdoff (1970), Kalecki (1972), Hunt (1972), Reich (1972), O'Connor (1973), and Weisskopf (1976) all fail to acknowledge the question of who ultimately pays for military production (the taxpayer). This means that there is no discussion of the impact of milex on the after-tax profit rate. Gottheil (1986) underscores the fact that military production is more capital intensive, which rises organic composition of capital, resulting in a decline in the average rate of profit. Cypher writes, in response to Gottheil (1986), that military sector research and development enhanced the technology of major constant capital categories such as computers, lowering the production cost in major civilian sectors. He also notes that research and development generally improve the productivity of labor, so that milex actually prevents the increase in the organic composition of capital and the fall in the rate of profit (Cypher, 1987a, 1987b).

Miller (1987) disagrees with this analysis, stating that milex leads to capital accumulation, as it is financed by wage taxation. The milex cannot be classified as "reproductive" nor "productive" expenditures, which means that they are detrimental to the long-run productivity and profitability potential of the economy. This is because milex diverts intellectual, financial, and material resources away from civilian industries, which can translate into a reduction of industrial productivity (Melman, 1965). This concept is reinforced by Hunt $(1972,141)$, who notes that "military spending keeps the capital-goods industry operating at near full capacity without raising the economy's productive capacity as rapidly as it would be the case if they provided capital goods for industry".

\subsection{Empirical Literature}

The validity of Baran and Sweezy's theory has been challenged by Szymanski (1973a). He tested Baran and Sweezy's argument that higher milex in monopoly capitalist countries leads to lower unemployment and higher growth rates for 18 major countries during the period of 1950-1968. Szymanski found that higher milex is associated with a lower rate of unemployment, but that it is harmful for economic growth. Therefore, he concludes that Baran and Sweezy's theory does not hold.

As a response to Szymanski's study, Sweezy (1973) noted that his methodology, not the specific empirical method he used, does not allow one to explain the theory appropriately. Sweezy first, notes that those 18 countries cannot be treated as independent entities because they are "interrelated parts of a single world capitalist system" with very unequal weights. Second, he argues that the Szymanski's model has "problems of theory and of the uses of theory in the interpretation of history" (Friedman, 1974, 709-710).

Szymanski's work was criticized by some other scholars as well. Friedman (1974) raises two critiques, that the model ignores the international context of the permanent arms economy and that it does not consider the analytical interconnections between politics and economics. He also argues that the model omits some important variables -as pointed out by Stevenson (1974) as well-, causing a robustness problem. In a similar manner, Zeitlin (1974, 1453) argued that Szymanski's test is irrelevant to Baran and Sweezy's theory in that it does not reflect the "monopoly" structure and that the data used does not reflect "time-order relationships". This is because in Baran and Sweezy's theory, milex, along with other indicators, is one mode of surplus; other indicators may include the sales interest and financial interest that help monopoly capitalism to function, as it is a system with a 
specific sociohistorical context of post-war America Zeitlin (1974, 1453-55)². Furthermore, Zeitlin rightly points out the fact that Baran and Sweezy believed that as the composition of milex changes fewer people would be employed. Stevenson (1974), in addition to the aforementioned critique, and in line with Zeitlin (1974) argues that Szymanski's use of only the 1968 milex is problematic, and his analysis ignores the Marxist law of uneven development, suffering from a non-dialectical approach.

In his reply to Sweezy and also Friedman, Stevenson and Zeitlin, Szymanski (1973b, 1974) rejects the critique of using the comparative method, and defends his conclusion that no empirical relationship between milex and economic prosperity in wealthy countries suffices to refute Baran and Sweezy's basic argument that milex is the major factor in preventing economic stagnation. Szymanski (1974) deals with other critiques in detail, providing further empirical analysis to suggest additional control variables such as 'deliberate prohibitions against military spending', 'external hostility', 'the role of labor parties', and 'the effect of destruction of WWII'. He argues that these new findings confirm the original results.

An exchange similar to the one between Szymanski and Friedman, Stevenson, and Zeitlin occurred among Smith (1977, 1978), and Hartley and McLean (1978) and Chester (1978), and among Pivetti (1992, 1994), and Dunne (1990) and Smith and Dunne (1994).

Smith (1977) investigated the effect of milex on major economic indicators on 15 major NATO countries for the 1960-1970 period. He concluded that, by crowding out investment that could have higher productivity otherwise, milex has a negative effect on economic growth. He argued that while the underconsumptionist view does not hold, milex still plays a crucial role in the maintenance of capitalism for strategic reasons.

Smith (1978)'s reply to Hartley and McLean (1978) and Chester (1978), as well as Green and Higgins (1977) who wrote on the Soviet Union (cited in Smith (1978)), and later on Smith (1980) on major 14 OECD countries for the 1954-1973 period, confirmed and strengthened the findings against the underconsumptionist view.

Later on, Pivetti (1992) argued that, unlike what Smith (1977, 1980), Dunne (1990) and Abell (1990) proposed, high military spending from 1947 to the late 1960s kept the effective demand high, leading to lower unemployment and a high growth rate in the US.

In their reply, Smith and Dunne (1994) strongly argued that both their works as well as some others provide counter-evidence to underconsumptionist view. Pivetti (1994) basically restated, without providing any empirical analysis, that the low level of unemployment from 1947 to the end of the 1960s coinciding with high milex, increasing unemployment, and lower milex from the 1960s to the end of 1970s, as well as declining unemployment during Reagan's military build-up, presents evidence against Smith and Dunne's 'military burden' argument.

More recently, some scholars have been interested in the effect of milex on the profit rate rather than on economic growth, bringing a new empirical approach to the issue in question. In this context, to the best of our knowledge, there are only four time-series studies, Georgiou (1992), Kollias and Maniatis (2003), Dunne et al. (2013), Elveren and Özgür (2018) and a panel study, Elveren and Hsu (2016).

Georgiou (1992) uses an OLS methodology to examine the effect of milex on profit rates in the UK, US and the former West Germany for the period of 1958-1987 with respect to Luxemburg's and Mandel's views. The study finds positive significant effect of milex on

\footnotetext{
${ }^{2}$ In fact, this critique was raised by Friedman (1974) and Stevenson (1974) as well.
} 
profit rates in the case of the US, and insignificant effects for other two countries. Kollias and Maniatis (2003) employ the autoregressive distributed lag model (ARDL) to find that while milex have a positive effect on the profit rate in the short run, they have an inverse relationship in the long run in the case of Greece during the 1962-1994 period. Dunne et al. (2013) examine the case of the US for the period of 1959-2010. Based on OLS and ARDL methods, the study provides some evidence on the positive long run relationship between the military burden and the profit rate. Finally, Elveren and Özgür (2018) examine the case of Turkey during the 1950-2008 period by employing ARDL and Markov-Switching method to find that while the during economic downturns military spending reduces the profit rates further, it boosts the profitability during the regular periods.

Finally, Elveren and Hsu (2016), in a Marxist framework like above studies, employ a panel ARDL lag model to analyze 24 OECD countries for the period of 1963-2008. Their findings suggest that while for the whole period there is positive linkage between milex and profit rates, in the post-1980 era the impact of milex is negative. The authors also find weak evidence that while for arms-exporting countries, there is positive linkage between milex and profit rates, the linkage is negative for non-arms-exporter countries.

In short, overall, the Marxist literature regarding the effect of milex on the economy presents diverse linkages based on different crisis theories with different underlying assumptions, and empirical studies are not conclusive.

\section{Data and Method}

\subsection{Data}

Marxist variables cannot be easily quantified or determined. How to construct these variables has resulted in the biggest controversy within Marxist Economics. This can be negotiated by using value theory, which entails obtaining measures that best fit Marxist categorizations $^{3}$ (Dunne, 1991; Elveren \& Hsu, 2016).

From Marx's perspective, profit rate can be defined as the total surplus value that is produced by productive labor divided by the total stock of fixed capital. Marxist scholars use corporate surplus and fixed capital stock respectively as proxies for surplus value and capital value, respectively, in empirical analysis.

Our dependent variable, profit, is the gross profit rate (the ratio of surplus value to invested capital), obtained from the Extended Penn World Tables v.4.0 (EPWT, 2017). It is calculated as

$$
\text { profit }=100 *(1-\text { wage share }) * \text { productivity of capital }
$$

where wage share is the share of the employee compensation as a component of Gross Domestic Product, measured in local currency at current prices; productivity of capital is the output-capital ratio as calculated using real Gross Domestic Product at 2005 purchasing power parity (Chain Index) over the estimated capital stock.

The EPWT data are aggregated national output measures, which uses the market valua-

${ }^{3}$ The price is a measure of value and Ricardo finds that values are proportional to prices. It is empirically proven that the value price distortion is very small (Ochoa (1984), Shaikh (1984), and Petrovic (1987) cited in Dunne (1991)). 
tion of outputs and the aggregated market valuation of different capital goods. Aggregation can be problematic because it does not display differences in capital measurements arising from price and composition in capital changes, as opposed to uniform changes in the quantity of capital.

Capital stock in EPWT can be found using the Perpetual Inventory Method (PIM). This method calculates investment based on the real investment share of GDP found in the Penn World Table v. 5.6, with straight-line depreciation (Foley \& Marquetti, 1997).

EPWT data faces some issues remaining from the original Penn World Tables data set (Foley \& Marquetti, 1997). These include concern over the data quality on investment. In addition, all categories are assumed to have the same short asset life because investment data is not classified by type of gross fixed capital formation. This means that the PIM procedure may underestimate the size of capital stock inconsistently across various countries with differing compositions of gross fixed capital formation.

For some missing countries and years, we utilize the profit rate sets calculated with the same method by Roberts (2012) and Maito (2016) to expand EPWT series, when the correlation between the EPWT and other set is at least as high as 0.87 .

Our key explanatory variable is the military burden. We use milex as a share of GDP recently provided by the Stockholm International Peace Research Institute (SIPRI, 2017). Milex may have a positive or negative effect on the profit rate depending on assumption and short-term or long-term classification.

Gini coefficient is the most popular indicator used for income inequality. However, Gini index has very sparse coverage in time, and it includes inconsistent definitions and different quality of data among countries and even within a country over time. Therefore, using Gini coefficient may cause unrobust and misleading results in the empirical analysis. Considering those problems, Galbraith et al. (1999) computed a measure for manufacturing pay-inequality by using Theil's formula (Theil, 1972), namely the University of Texas Inequality Project- United Nations Industrial Development Organization (UTIP-UNIDO) data set. UTIP also calculated the Estimated Household Income Inequality (EHII, 2018) by combining manufacturing pay inequality index and Deininger and Squire (1996) data sets in the Gini format ${ }^{4}$. EHII data set has 3872 observations covering 149 countries for the period of 1963-2008.

The Marxist approach to income distribution centers on the extraction of surplus value. Marx found that wages are determined with respect to a subsistence level and the relative bargaining power. The vastness of the industrial reserve army pushes the wages down. Therefore, labor market bargaining conditions determine income distribution. In the long run, however, increasing inequality can reduce capital accumulation, thereby profit rates, as reduces the aggregate demand.

Data for economic growth is taken from the World Development Indicators (2017) set provided by the World Bank. Economic growth leads to higher capital accumulation. That is, it is expected that growth is associated with higher rates of profit.

Unemployment rate data is obtained from the World Development Indicators (2017). A rise in unemployment pushes down wage bargaining power and lowers the wage rate, increasing the rate of surplus value as well as the rate of profit. However, rising unemploy-

${ }^{4}$ See Galbraith and Kum (2005) and UTIP (2018) for details. 
ment puts reduces effective demand. This has the effect of raising the organic composition of capital and possibly reducing the profit rate simultaneously.

We created three dummy variables. If a country exports more arms than it imports, then we call it net arms exporter, netexpo. This variable is calculated at year level. We also categorize countries as arms exporter ${ }^{5}$ or arms importer ${ }^{6}$ according to their role in arms trade. We did not include countries in either category if their roles in arms-trade is not obvious.

Our data includes 32 major countries ${ }^{7}$ for the period of 1963-2008. Figure 1 shows the trends of two main variables, global profit (e.g. average of profit rate) and average of military burden (e.g. milex/GDP).

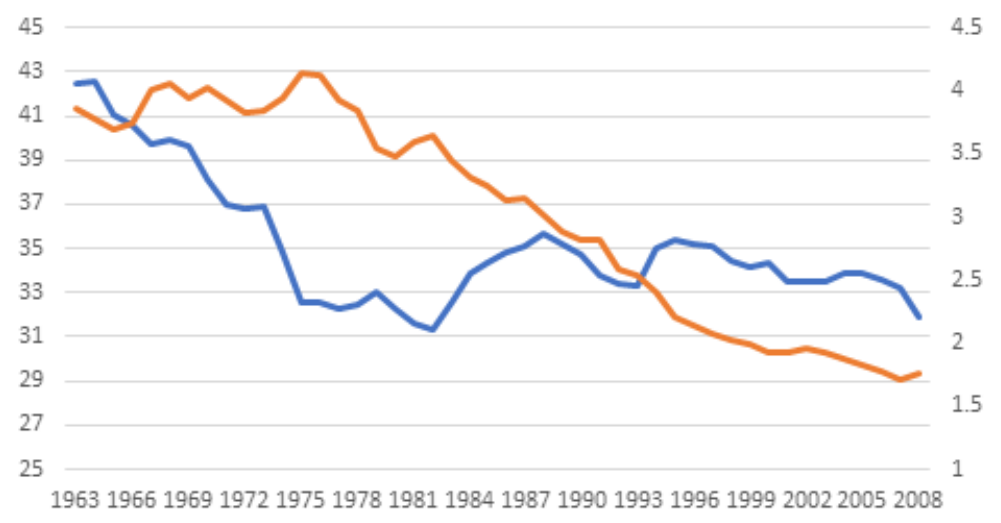

Global Proft —Military Expend ture/GDP

Figure 1: The trends of the rate of profit and milex

Source: Author's compilation

\subsection{Method}

We employ a dynamic specification in a panel data context to consider significant lagged effects of the dependent variable which cause serial correlation with itself ${ }^{8}$. The model to estimate is as follows:

$$
\begin{gathered}
\text { Inprofit }_{i, t}=\beta_{0} \text { Inprofit }_{i, t-1}+\beta_{1} \text { lnmilex }_{i, t}+\beta_{2} \text { lnunemp }_{i, t}+ \\
\beta_{3} \text { Ingrowth }_{i, t}+\beta_{4} \text { lnglobal }_{i, t}+\beta_{5} \text { lnineq }_{i, t}+ \\
\beta_{6} \text { lnnetexpo }_{i, t}+\alpha_{i}+\alpha_{t}+u_{i, t}
\end{gathered}
$$

where the subscripts $i$ and $t$ refer countries and years, respectively. profit $i t$ is the profit rate, profit $i t-1$ denotes the lagged profit rate, milex $_{i t}$ is milex as a share of GDP, growth is

\footnotetext{
${ }^{5}$ France, Sweden, Switzerland, UK and US.

${ }^{6}$ Argentina, Australia, Belgium, Brazil, Chile, Greece, India, Japan, Mexico, New Zealand, Norway, Portugal, South Africa, South Korea, Spain, Turkey.

7 Argentina, Australia, Austria, Belgium, Brazil, Canada, Chile, China, Denmark, Finland, France, Germany, Greece, India, Ireland, Israel, Italy, Japan, Luxembourg, Mexico, Netherlands, New Zealand, Norway, Portugal, South Africa, South Korea, Spain, Sweden, Switzerland, Turkey, UK, and US.

8 Section 3 benefits from Töngür and Elveren (2017) and Töngür, Hsu, and Elveren (2015).
} 
economic growth rate, globalprofit represents global profit rate (e.g. average of profit rate), ineq is income inequality (e.g. EHII), and finally netexpo is the dummy for net exporting countries as explained above (the analysis is repeated with dummies of arms exporting and arms importing countries). The variables $\alpha_{i}$ and $\alpha_{t}$ denotes time invariant country specific effects and time specific effects, respectively. The last term $u_{i t}$ is idiosyncratic error component.

The dynamic model violates the assumption of strict exogeneity of the estimators since the existence of country specific effects in Equation (1) creates a correlation between the lagged dependent variable and the individual fixed effect. Therefore, employing ordinary least squares method gives inconsistent and upward biased estimates for the coefficient of the lagged dependent variable (Hsiao, 1986; Baltagi, 1995). Fixed effects estimator, on the other hand, leads to a downward bias for the estimated parameter (Nickell, 1981). Hence, both methods would yield biased estimates of independent variables.

To address these problems, Arellano and Bond (1991) suggest using a Generalized Method of Moment (GMM) estimation. The dynamic growth equation is expressed in the first differences to remove country specific effects, and in this first differenced equation they use lagged values of the right-hand side variables as instruments in the regression (GMMDIF). Blundell and Bond (1998) also suggest using additional level moment conditions to obtain system GMM estimation (GMM-SYS). In GMM-SYS, lagged first-differences are used as instruments for equations in levels, in addition to the lagged levels as instruments in the first differences. By doing so, GMM-SYS utilizes all information available in the data (Bond, 2002). We consider all major estimation issues noted in Roodman (2006) and Roodman (2009). Moreover, year dummies are included in all regressions to control for possible macroeconomic shocks.

\section{Results and Discussion}

We provide both fixed effect and dynamic fixed effect results for the purpose of comparison. However, we will focus on the results of GMM analysis.

Considering the results of fixed effect and dynamic fixed effect in Table 1 and Table 2, respectively, one can make four general points: i) As expected, the significant sign of global profit suggests that there is a global pattern of profit rates. ii) Overall, milex has positive impact on profit rates. iii) As expected, higher rate of unemployment and higher income inequality are associated with higher profit rates. iv) It is likely that net arms-exporter countries have higher profit rates than other countries, and, milex increases profit rates only in the case of arm-exporting countries (Model 1.3 vs Model 1.4), or positive impact of milex on profit rates is higher in the case of arms-exporting countries than arms-importing countries (Model 2.3 vs Model 2.4).

We emphasize the results of GMM method as we discussed in methodology section. The results are presented in Table 3. Models 3.1 and 3.2 provide results of Difference GMM. While Model 3.1 does not include netexpo variable Model 3.2 does. Models 3.3 and 3.4 reiterate them with the System GMM. Tables also provide the information on some usual econometric issues. Accordingly, the Hansen test to over-identify restrictions can test the null hypothesis regarding adequate instruments, while Arellano-Bond tests for the serial correlations test the presence of serial correlation in the first-differenced residuals. The null hypothesis would be that residuals are serially uncorrelated; if this is rejected for AR (1), 
Table 1: Fixed Effect Results

\begin{tabular}{|c|c|c|c|c|}
\hline Variables & 1.1 & 1.2 & 1.3 Exporters & 1.4 Importers \\
\hline \multirow[t]{2}{*}{ milex } & $22.510^{*}$ & $22.845^{*}$ & $75.785^{* * *}$ & 62.211 \\
\hline & [11.768] & [11.999] & {$[24.800]$} & {$[37.755]$} \\
\hline \multirow[t]{2}{*}{ unemp } & $0.190^{* * *}$ & $0.171^{* * *}$ & $0.475^{* * *}$ & $0.362^{* * *}$ \\
\hline & [0.061] & [0.062] & {$[0.079]$} & [0.099] \\
\hline \multirow[t]{2}{*}{ growth } & $33.209^{* * *}$ & $33.218^{* * *}$ & $45.869^{* * *}$ & $34.884^{* * *}$ \\
\hline & [4.071] & [4.267] & [7.043] & [6.175] \\
\hline \multirow[t]{2}{*}{ globalprofit } & $1.162^{* * *}$ & $1.146^{* * *}$ & $0.683^{* * *}$ & $2.016^{* * *}$ \\
\hline & {$[0.102]$} & {$[0.103]$} & [0.100] & {$[0.190]$} \\
\hline \multirow[t]{2}{*}{ ehii } & $0.258^{* * *}$ & $0.196^{*}$ & $0.675^{* * *}$ & 0.195 \\
\hline & [0.099] & {$[0.102]$} & [0.122] & {$[0.159]$} \\
\hline netexpo & & $\begin{array}{c}1.288^{* *} \\
{[0.586]}\end{array}$ & & \\
\hline Constant & $\begin{array}{c}-18.846^{* * *} \\
{[5.298]}\end{array}$ & $\begin{array}{c}-16.151^{* * *} \\
{[5.493]}\end{array}$ & $\begin{array}{c}-21.756^{* * *} \\
{[5.027]}\end{array}$ & $\begin{array}{c}-45.271^{* * *} \\
{[9.834]}\end{array}$ \\
\hline Observations & 1,007 & 972 & 153 & 473 \\
\hline R-squared & 0.213 & 0.208 & 0.61 & 0.272 \\
\hline F-Test & 72.24 & 73.89 & 155.07 & 65.75 \\
\hline Number of id & 32 & 31 & 5 & 16 \\
\hline
\end{tabular}

Standard errors in brackets ${ }^{* * *} p<0.01,{ }^{* *} p<0.05,{ }^{*} p<0.1$

it implies that a dynamic specification is needed. If the null hypothesis is not rejected, we then have evidence that there is no second-order serial correlation and the GMM estimator is consistent.

The results presented in Table 3 are very similar to the ones in Table 1 and Table 2. Accordingly, i) Globalprofit controls for the cross sectional dependence. The significant global profit suggests that there is a global pattern for the profit rates of individual countries. This is not unexpected as one considers the global characteristics of capital, and the set of countries that are major part of global economy.

ii) Both the rate of unemployment and income inequality are positively associated with the profit rates. As noted above increase in unemployment may have counter effects on the rate of profit. On the one hand, a higher rate of unemployment results in lower wage bargaining power and reduces the wage rate, increasing the rate of surplus value and the rate of profit. On the other hand, it may reduce the effective demand, pushing up the organic composition of capital and potentially reducing the rate of profit. In this context, the findings suggest that the positive impact of unemployment is much more significant than its potential negative impact. That is, our findings confirm the reserve army of the unemployed argument. The findings also show that as income inequality increases the rate of profits increases as well. In a similar manner to that way unemployment affects effective demand and thereby profit rates, inequality also has impact on the profit rates. Higher inequality can increase profit rate, as it reduces the share of labor in national income. However, the inequality may have a negative impact on the rates of profit in the long run. According to the paradox of thrift, if wage income is redistributed from low-to high-saving classes, 
Table 2: Dynamic Fixed Effect Results

\begin{tabular}{|c|c|c|c|c|}
\hline Variables & 2.1 & 2.2 & 2.3 Exporters & 2.4 Importers \\
\hline \multirow[t]{2}{*}{ Lag.profit } & $0.904^{* * *}$ & $0.907^{* * *}$ & $0.791^{* * *}$ & $0.896^{* * *}$ \\
\hline & {$[0.010]$} & {$[0.010]$} & {$[0.038]$} & {$[0.014]$} \\
\hline \multirow[t]{2}{*}{ milex } & $6.475^{*}$ & 6.154 & $37.149 * * *$ & $24.793^{* *}$ \\
\hline & {$[3.757]$} & {$[3.788]$} & {$[12.447]$} & {$[12.126]$} \\
\hline \multirow[t]{2}{*}{ unemp } & $0.096^{* * *}$ & $0.092^{* * *}$ & $0.173^{* * *}$ & $0.099^{* * *}$ \\
\hline & {$[0.019]$} & {$[0.019]$} & {$[0.042]$} & {$[0.032]$} \\
\hline \multirow[t]{2}{*}{ growth } & $14.502^{* * *}$ & $13.870^{* * *}$ & $26.950 * * *$ & $13.031^{* * *}$ \\
\hline & {$[1.314]$} & [1.362] & {$[3.611]$} & {$[2.011]$} \\
\hline \multirow[t]{2}{*}{ globalprofit } & $0.092^{* * *}$ & $0.090 * * *$ & -0.002 & $0.222^{* * *}$ \\
\hline & {$[0.034]$} & {$[0.034]$} & {$[0.059]$} & {$[0.067]$} \\
\hline \multirow[t]{2}{*}{ ehii } & $0.067 * *$ & $0.059^{*}$ & $0.205^{* * *}$ & 0.07 \\
\hline & {$[0.032]$} & {$[0.032]$} & {$[0.065]$} & {$[0.051]$} \\
\hline \multirow[t]{2}{*}{ netexpo } & & 0.119 & & \\
\hline & & {$[0.185]$} & & \\
\hline \multirow[t]{2}{*}{ Constant } & $-3.961^{* *}$ & $-3.637^{* *}$ & -3.502 & $-8.713^{* * *}$ \\
\hline & {$[1.697]$} & {$[1.738]$} & {$[2.643]$} & {$[3.208]$} \\
\hline Observations & 1,007 & 972 & 153 & 473 \\
\hline R-squared & 0.92 & 0.921 & 0.904 & 0.925 \\
\hline F-Test & 3.86 & 3.59 & 7.07 & 3.93 \\
\hline Number of id & 32 & 31 & 5 & 16 \\
\hline
\end{tabular}

aggregate demand is reduced because leakage increases. Where there is low-saving, classes are able to accumulate debt given access to finance and rising asset prices, which reduce the negative effect of the increase in inequality in the short run. Debt-fueled consumption does not last long because low income households will be forced to save given increased interest obligations, which increases the likelihood of entering a debt burdened recession (Palley, 2002). Vasudevan (2016) analyzes the effect of inequality on profitability, finding, along with others such as Palley (2002), Dutt (2006), Carvalho and Rezai (2016), that high aggregate demand arises from "debt-fueled consumption" even in the face of stagnant wages and rising inequality. Vasudevan (2016) shows accumulation is reduced due to exogenous consumer borrowing arising from increased inequality. Our results show that higher income inequality is strongly associated with higher rates of profit. We acknowledge that our results by no means refusal of the above theoretical statements by Vasudevan (2016) and others, but rather they are just general evidence on the positive relationship between income inequality and profit rates.

iii) In three out of four model specifications, milex has a positive impact on profit rates. Although this is a very robust result, as argued in Elveren and Hsu (2016), it is rational expect differing effect in terms of the countries' roles in arms trade. This arises from the fact that the structure of the military burden, not just the size, matters. The negative impact of armament production is more likely to arise in arms-importing countries than in arms-exporting countries. In a similar manner, it is reasonable to expect that positive 
impact of milex, such as increasing surplus value by increasing labor productivity, is more likely to occur in the arms-exporting countries. In fact, ignoring the role of countries in arms-trade might be one reason for the conflicting results of the literature on the effect of milex on economic growth. In fact, our results suggest that it is more likely that being net arms-exporting increases the profit rates. This finding is supported by the results of fixed effect model showed in Table 1 as well.

Table 3: GMM Results

\begin{tabular}{|c|c|c|c|c|}
\hline Variables & 3.1 GMM-DIF & 3.2 GMM-DIF & 3.3 GMM-SYS & 3.4 GMM-SYS \\
\hline \multirow{2}{*}{ Lag.profit } & $0.889^{* * *}$ & $0.910^{* * *}$ & $0.869^{* * *}$ & $0.906^{* * *}$ \\
\hline & {$[0.022]$} & {$[0.023]$} & [0.028] & [0.033] \\
\hline \multirow[t]{2}{*}{ milex } & $20.707 * * *$ & 15.842 & $22.156^{* * *}$ & $17.885^{*}$ \\
\hline & {$[6.586]$} & [15.933] & [7.359] & {$[9.145]$} \\
\hline \multirow[t]{2}{*}{ unemp } & $0.225^{* * *}$ & $0.195^{* * *}$ & $0.167^{* * *}$ & $0.107^{*}$ \\
\hline & [0.046] & {$[0.054]$} & [0.033] & [0.055] \\
\hline \multirow[t]{2}{*}{ growth } & $23.041^{* * *}$ & $22.910 * * *$ & $23.553^{* * *}$ & $23.712^{* * *}$ \\
\hline & [1.079] & [1.627] & [1.668] & [2.052] \\
\hline \multirow[t]{2}{*}{ globalprofit } & $0.118^{* * *}$ & $0.095^{* *}$ & $0.109^{*}$ & 0.013 \\
\hline & {$[0.033]$} & {$[0.039]$} & [0.060] & {$[0.060]$} \\
\hline \multirow[t]{2}{*}{ ehii } & $0.280 * * *$ & $0.284^{* * *}$ & $0.067^{* * *}$ & $0.073^{* *}$ \\
\hline & {$[0.071]$} & [0.099] & [0.018] & {$[0.028]$} \\
\hline \multirow[t]{2}{*}{ netexpo } & & $0.112^{* *}$ & & $0.209^{* *}$ \\
\hline & & {$[0.051]$} & & {$[0.105]$} \\
\hline \multirow[t]{2}{*}{ Constant } & & & $-4.615^{* *}$ & -2.342 \\
\hline & & & [1.863] & {$[2.022]$} \\
\hline Observations & 963 & 929 & 1,007 & 972 \\
\hline Number of id & 32 & 31 & 32 & 31 \\
\hline Wald & 26117 & 25056 & 4493 & 6009 \\
\hline Hansen & -0.991 & -0.996 & -0.995 & -0.999 \\
\hline $\operatorname{AR}(1)$ & -0.057 & -0.07 & -0.066 & -0.081 \\
\hline $\operatorname{AR}(2)$ & -0.898 & -0.875 & -0.92 & -0.887 \\
\hline
\end{tabular}

Standard errors in brackets ${ }^{* * *} p<0.01,{ }^{* *} p<0.05,{ }^{*} p<0.1$. p-values for Hansen and AR tests are in parentheses.

Finally, we investigate the direction of causality between profit rates and milex by employing a non-causality test for heterogeneous balanced panel data suggested by Dumitrescu and Hurlin (2012). The Dumitrescu- Hurlin test ${ }^{9}$ is the average of the test statistics of stan-

${ }^{9}$ We employed the test in following form, where, $\alpha_{i}$ are assumed be fixed in the time dimension:

$$
\begin{aligned}
& \Delta \text { Profit }_{i, t}=\alpha_{i}+\sum_{k=1}^{p} \gamma_{i}^{k} \Delta \text { Profit }_{i, t-k}+\sum_{k=1}^{p} \gamma_{i}^{k} \Delta \text { Milex }_{i, t-k}+v_{i, t} \\
& \Delta \text { Milex }_{i, t}=\alpha_{i}+\sum_{k=1}^{p} \gamma_{i}^{k} \Delta \text { Milex }_{i, t-k}+\sum_{k=1}^{p} \gamma_{i}^{k} \Delta \text { Profit }_{i, t-k}+v_{i, t}
\end{aligned}
$$


dard Granger Causality regressions for each cross-section individually ${ }^{10}$. There are two main findings (see Table 4). First, there exist bidirectional panel Granger causality between military burden and profit rates in one-third of the countries. Second, it is more likely that while profit rates Granger causes milex in importer countries, in the case of exporter countries causality is running from milex to profit rates.

Table 4: Granger-causality test results

\begin{tabular}{|l|r|r|r|r|}
\hline & \multicolumn{2}{|c|}{ Milex $\longrightarrow$ Profit } & \multicolumn{2}{c|}{ Profit $\longrightarrow$ Milex } \\
\hline Panels & \multicolumn{4}{|c|}{ Panel P-values } \\
All countries (32) & Lags: 1 & Lags: 2 & Lags: 1 & Lags: 2 \\
Exporters (5) & 0 & 0 & $3 \mathrm{E}-04$ & $7 \mathrm{E}-04$ \\
Importers (16) & $1 \mathrm{E}-04$ & 0.02 & 0.327 & 0.961 \\
\hline & 0.04 & 0.088 & 0.002 & 0 \\
\hline & \multicolumn{5}{|c|}{ Number of countries with P-value $<40.10$} \\
All countries (32) & Lags: 1 & Lags: 2 & Lags: 1 & Lags: 2 \\
Exporters (5) & 10 & 11 & 10 & 9 \\
Importers (16) & 3 & 3 & 2 & 0 \\
\hline
\end{tabular}

Notes: Both variables in first differences. $\longrightarrow$ means "does Granger cause". Null hypothesis is no causality.

The Granger causality results, to a certain degree, strengthen our results by clearly pointing out the difference between arms-exporting and arms-importing countries in terms of the direction of causality between milex and profit rates. While milex leads to higher profit rates in the case of exporting countries like the US, higher profit rates (e.g. capital accumulation) allow for larger military budgets.

Our findings support the findings of Elveren and Hsu (2016). We confirm the positive impact of the rate of unemployment on the rate of profits. More importantly, our findings support and strengthen the differing effect of milex on arm-exporting and arms-importing countries. Examining this thesis with an extended set of country and with a new dummy variable, we find the same result. Moreover, this study shows that these results are not sensitive to model and method choice. Incorporating a crucial variable of inequality, which is influenced by both milex and profit rates, does not change the results.

\section{Conclusion}

The goal of this study was to contribute to the literature by examining an important economic issue, the effect of milex on the profit rates by considering the fact that there are conflicting theories, and few studies providing inconclusive empirical findings. In fact, there has been only one panel data study on 24 OECD countries (Elveren \& Hsu, 2016). Departing from that study, this paper provided some new evidence on the relationship in question in four aspects. First, we this study relies on an extended data set that includes major countries like Argentina, Germany, China, India, Brazil, South Korea, South Africa, and Mexico. Second, considering the literature that underscores the role of income inequality

10 This analysis is taken from Elveren and Dunning (2017). 
in the context of effect of milex on the economy (Ali, 2007; Töngür \& Elveren, 2017; Taşıran \& Elveren, 2017), we also examined the potential impact of inequality. Third, considering a key finding of Elveren and Hsu (2016), we improve the dummy variables to better test the difference between arms-exporting and arms-importing countries. Finally, we employed a few different estimation methods, as part of our robustness analysis, and Granger causality test to provide more information on the relationship between two key variables in question.

Accordingly, there are three major findings of this study. First, although the positive effect of milex on profit rates is a very robust result in general, the findings are significantly different with respect to the role of countries in arms trade. Different model specifications with different dummies suggest that it is more likely that being net arms-exporting increases the profit rates. This strengthens the early findings of Elveren and Hsu (2016).

Second, both the rate of unemployment and income inequality are positively associated with the profit rates. Positive (i.e. increasing) impact of unemployment on profit rates through lowering wage bargaining power and reducing the wage rate is higher than its negative effect via reducing the effective demand. In other words, this finding confirms the reserve army of the unemployed argument. In a similar manner to that way unemployment, inequality may have negative or positive effects. The positive association between higher inequality and profit rates is straightforward. However, the inequality may have a negative impact on the rates of profit in the long run. Because, redistribution of income from low- to high-saving classes reduces aggregate demand. Our results show that positive (e.g. increasing) impact of income inequality on profit rates outweighs its negative impact.

Finally, our findings suggest that it is more likely that while profit rates Granger causes milex in importer countries, in the case of exporter countries causality is running from milex to profit rates. 


\section{References}

Abell, J. D. (1990). Defence Spending and Unemployment Rates: An Empirical Analysis Disaggregated by Race. Cambridge Journal of Economics, 14(4), 405-419. doi:10.1093/oxfordjournals.cje.a035143

Ali, H. E. (2007). Military Expenditures and Inequality: Empirical Evidence from Global Data. Defence and Peace Economics, 18(6), 519-535. doi:10.1080/10242690701331501

Alptekin, A., \& Levine, P. (2012). Military Expenditure and Economic Growth: A Meta-analysis. European Journal of Political Economy, 28(4), 636-650. doi:10.1016/j.ejpoleco.2012.07.002

Arellano, M., \& Bond, S. (1991). Some Tests of Specification for Panel Data: Monte Carlo Evidence and an Application to Employment Equations. Review of Economic Studies, 58(2), 277-297. doi:10.2307/2297968

Baltagi, B. H. (1995). Econometric Analysis of Panel Data. Wiley.

Baran, P. A., \& Sweezy, P. M. (1966). Monopoly Capital: An Essay on the American Economic and Social Order. Monthly Review Press, New York and London.

Basu, D., \& Vasudevan, R. (2013). Technology, Distribution and the Rate of Profit in the US Economy: Understanding the Current Crisis. American Economic Review, 37(1), 57-89. doi:10.1093/cje/bes035

Blundell, R., \& Bond, S. (1998). Initial Conditions and Moment Restrictions in Dynamic Panel Data Models. Journal of Econometrics, 87(1), 115-143. doi:10.1016/S03044076(98)00009-8

Bond, S. (2002). Dynamic Panel Data Models: A Guide to Micro Data Methods and Practice (Centre for Microdata Methods and Practice (CEMMAP) Working Papers No. CWP09/02).

Carvalho, L., \& Rezai, A. (2016). Personal Income Inequality and Aggregate Demand. Cambridge Journal of Economics, 40(2), 491-505. doi:10.1093/cje/beu085

Chester, E. (1978). Military Spending and Capitalist Stability. Cambridge Journal of Economics, 2(3), 293-298. doi:10.1093/oxfordjournals.cje.a035392

Coulomb, F. (2004). Economic Theories of Peace and War. Routledge, London and New York.

Coulomb, F., \& Bellais, R. (2008). The Marxist Analysis of War and Military Expenditures, Between Certainty and Uncertainty. Defence and Peace Economics, 19(5), 351-359. doi:10.1080/10242690802354345

Cypher, J. (1987a). Military Spending, Technical Change, and Economic Growth: A Disguised form of Industrial Policy? Journal of Economic Issues, 21(1), 33-59. doi:10.1080/00213624.1987.11504597

Cypher, J. (1987b). Military Production and Capital Accumulation: A Comment. Journal of Post-Keynesian Economics, 10(2), 304-309. doi:10.1080/01603477.1987.11489679

Deininger, K., \& Squire, L. (1996). A New Data Set Measuring Income Inequality. World Bank Economic Review, 10(3), 565-591. doi:10.1093/wber/10.3.565

Dumitrescu, E.-I., \& Hurlin, C. (2012). Testing for Granger Non-causality in Heterogeneous Panels. Economic Modeling, 29(4), 1450-1460. doi:10.1016/j.econmod.2012.02.014 
Duménil, G., \& Lévy, G. (2011). The Crisis of the Early 21st Century: A Critical Review of Alternative Interpretations [Mimeo]. http://citeseerx.ist.psu.edu/viewdoc/ download?doi=10.1.1.473.5051\&rep=rep1\&type=pdf.

Dunne, J. P. (1990). The Political Economy of Military Expenditure: An Introduction. Cambridge Journal of Economics, 14(4), 395-404. doi:10.1093/oxfordjournals.cje.a035142

Dunne, J. P. (1991). Quantitative Marxism. Cambridge: Polity Press.

Dunne, J. P., Pieroni, L., \& d'Agostino, G. (2013). Military Spending and the Falling Rate of Profit in the US [Mimeo].

Dunne, J. P., \& Uye, M. (2010). Military Spending and Development. In A. T. H. Tan (Ed.), The Global Arms Trade: A Handbook (p. 293-305). Routledge, London.

Dutt, A. K. (2006). Maturity, Stagnation and Consumer Debt: A Steindlian Approach. Metroeconomica, 57(3), 339-364. doi:10.1111/j.1467-999X.2006.00246.x

Elveren, A. Y., \& Dunning, R. (2017). Do Military Expenditures Boost Profit Rates? (Munich Personal RePEc Archive (MPRA) No. 81143).

Elveren, A. Y., \& Hsu, S. (2016). Military Expenditures and Profit Rates: Evidence from OECD Countries. Metroeconomica, 67(3), 551-577. doi:10.1111/meca.12111

Elveren, A. Y., \& Özgür, G. (2018). The Effect of Military Expenditures on the Profit Rates in Turkey (Munich Personal RePEc Archive (MPRA) No. 88848).

Engels, F. (1877). Anti-Dühring. http://www .marxists.org/archive/marx/works/1877/ anti-duhring/ch15.htm\#061.

Engels, F. (1893). Can Europe Disarm? In Karl Marx Frederick Engels Collected Works.

Estimated Household Income Inequality. (2017). . https://sites.google.com/a/ newschool .edu/duncan-foley-homepage/home/EPWT.

Extended Penn World Tables. (2018). . https://utip.lbj.utexas.edu/.

Foley, D., \& Marquetti, A. (1997). Economic Growth from a Classical Perspective. In International Colloquium on Money, Growth, Distribution and Structural Change: Contemporaneous Analysis. https://pdfs.semanticscholar.org/85d8/ d0f3fca9c9c1e42fb72992c4503979811440.pdf.

Friedman, S. R. (1974). An Alternative Model to Szymanski's. American Journal of Sociology, 79(6), 1459-1462. doi:10.1086/225712

Galbraith, J. K., Jiaqing, L., \& Darity, J. W. A. (1999). Measuring the Evolution of Inequality in the Global Economy (University of Texas Inequality Project (UTIP) Working Paper No. 7).

Galbraith, J. K., \& Kum, H. (2005). Estimating the Inequality of Households Incomes: Toward a Dense and Consistent Global Data Set. Review of Income and Wealth, 51(1), 115-143. doi:10.1111/j.1475-4991.2005.00147.x

Georgiou, G. (1983). The Political Economy of Military Expenditures. Capital \& Class, 7(1), 183-205. doi:10.1177/030981688301900108

Georgiou, G. (1992). Military Expenditure and the Rate of Profit: Some Empirical Results. International Review of Applied Economics, 16(3), 344-361. doi:10.1080/758534266

Gottheil, F. (1986). Marx versus Marxists on the Role of Military Production in Capitalist Economies. Journal of Post-Keynesian Economics, 2(8), 563-73. doi:10.1080/01603477.1986.11489584

Green, D. W., \& Higgins, C. I. (1977). SOVMOD I: A Macro-econometric Model of the Soviet Union. Academic Press, London. 
Hartley, K., \& McLean, P. (1978). Military Expenditure and Capitalism: A Comment. Cambridge Journal of Economics, 2(3), 287-292. doi:10.1093/oxfordjournals.cje.a035391

Hsiao, C. (1986). Analysis of Panel Data. Cambridge University of Press, Cambridge.

Hunt, E. K. (1972). Property and Prophets. Harper and Row, New York.

Kaldor, M. (1977). The Role of Arms in Capitalist Economies: The Process of Overdevelopment and Underdevelopment. In D. Carleton \& C. Schaerf (Eds.), Arms Control and Technological Innovation. Croom Helm, London.

Kalecki, M. (1972). he Last Phase in the Transformation of Capitalism. Monthly Review Press, New York.

Kidron, M. (1970). Western Capitalism Since the War Revised Edition. Pelican Books, Harmondsworth.

Kollias, C., \& Maniatis, T. (2003). Military Expenditure and the Profit Rate in Greece. Defence and Peace Economics, 14(2), 117-127. doi:10.1080/10242690302920

Luxemburg, R. (1913[2015]). The Accumulation of Capital. Mansfield Centre, CT: Martino Publishing.

Magdoff, H. (1970). Militarism and Imperialism. The American Economic Review, 60(2), 237-42. doi:10.14452/MR-021-09-1970-02_1

Maito, E. E. (2016). The Historical Transience of Capital Datasets [Mimeo]. https://uba.academia.edu/EstebanMaito/The-Historical-Transience-of -Capital-Datasets.

Mandel, E. (1978). Late Capitalism. Verso, New York.

Marx, K. (1848a). Manifesto of the Communist Party. https://www.marxists.org/ archive/marx/works/1848/communist-manifesto/index.htm.

Marx, K. (1848b). The Discourse on Free Trade. www.marxists.org/archive/marx/ works/1848/free-trade/.

Melman, S. (1965). Our Depleted Society. Holt, Rinehart and Winston, New York.

Miller, J. (1987). Military Spending and Economic Crises: A Comment on Gottheil and Riddell. Journal of Post-Keynesian Economics, 10(2), 310-318. doi:10.1080/01603477.1987.11489680

Nickell, S. (1981). Biases in Dynamic Models with Fixed Effects. Econometrica, 49(6), 1417-1426. doi:10.2307/1911408

Ochoa, E. M. (1984). Labour Values and Prices of Production: An Interindustry Study of the US Economy, 1947-1972 (PhD Thesis). Ann Arbor, MI.

O'Connor, J. (1973). The Fiscal Crisis of the State. St Martin's Press, New York.

Palley, T. (2002). Economic Contradictions Coming Home to Roost? Does the U.S. Economy Face a Long-term Aggregate Demand Generation Problem? Journal of Post Keynesian Economics, 25(1), 9-32. doi:10.1016/j.exis.2015.02.008

Petrovic, P. (1987). The Deviation of Production Prices from Labour Values: Some Methodology and Empirical Evidence. Cambridge Journal of Economics, 11(3), 197-210. doi:10.1093/oxfordjournals.cje.a035026

Pivetti, M. (1992). Military Spending as a Burden on Growth: An 'Underconsumptionist' Critique. Cambridge Journal of Economics, 16(4), 373-384. doi:10.1093/oxfordjournals.cje.a035209

Pivetti, M. (1994). Effective demand, 'marxo-marginalism' and the economics of military spending: A rejoinder. Cambridge Journal of Economics, 18(5), 523-527. doi:doi.org/10.1093/oxfordjournals.cje.a035288 
Purdy, D. (1973). The Theory of the Permanent Arms Economy-A Critique and an Alternative. Bulletin of the Conference of Socialist Economists, 5(1), 12-33.

Reich, M. (1972). Does the US Economy Require Military Spending? The American Economic Review, 62(1/2), 296-303.

Roberts, M. (2012). A World Rate of Profit [Mimeo]. http://thenextrecession.files . wordpress.com/2012/09/a-world-rate-of-profit.pdf.

Roodman, D. (2006). How to Do xtabond2: An Introduction to "Difference" and "System" GMM in Stata (Center for Global Development Working Paper No. 103).

Roodman, D. (2009). How to Do xtabond2: An Introduction to Difference and System GMM in Stata. Stata Journal, 9(1), 86-136.

Rowthorn, B. (1980). Capitalism Conflict $\mathcal{E}$ Inflation Essays in Political Economy. Lawrence and Wishart, London.

Shaikh, A. (1984). The Transformation from Marx to Sraffa. In E. Mandel \& A. Freeman (Eds.), Ricardo, Marx, Sraffa: The Langston Memorial Volume (p. 293-305). Verso, London.

SIPRI (Stockholm International Peace Research Institute). (2017). . www. sipri.org.

Smith, R. (1977). Military Expenditure and Capitalism. Cambridge Journal of Economics, 1(1), 61-76. doi:10.1093/oxfordjournals.cje.a035351

Smith, R. (1978). Military Expenditure and Capitalism: A Reply. Cambridge Journal of Economics, 2(3), 299-304. doi:10.1093/oxfordjournals.cje.a035393

Smith, R. (1980). Military Expenditure and Investment in OECD Countries, 1954-1973. Journal of Comparative Economics, 4(1), 19-32. doi:10.1016/0147-5967(80)90050-5

Smith, R. (1983). Aspects of Militarism. Capital \& Class, 7(1), 17-30. doi:10.1177/030981688301900102

Smith, R., \& Dunne, P. (1994). Is Military Spending a Burden? A 'Marxomarginalist' Response to Pivetti. Cambridge Journal of Economics, 18(5), 515-521. doi:10.1093/oxfordjournals.cje.a035287

Stevenson, P. (1974). A Defense of Baran and Sweezy. American Journal of Sociology, $79(6), 1456-1459$. doi:10.1086/225711

Sweezy, P. (1973). Comments on Szymanski's Paper 'Military Spending and Economic Stagnation'. The American Journal of Sociology, 79(3), 709-710. doi:10.1086/225593

Szymanski, A. (1973a). Military Spending and Economic Stagnation. American Journal of Sociology, 79(1), 1-14. doi:10.1086/225503

Szymanski, A. (1973b). Reply to Sweezy. American Journal of Sociology, 79(3), 710-711. doi:10.1086/225594

Szymanski, A. (1974). A reply to Friedman, Stevenson, and Zeitlin. American Journal of Sociology, 79(6), 1462-1477. doi:10.1086/225713

Taşıran, A. C., \& Elveren, A. Y. (2017). Soft Modelling of Military Expenditures, Inequality and Profits [Mimeo]. https://www. aeaweb.org/conference/2017/preliminary/ paper/DRSifQkh.

Theil, H. (1972). Statistical Decomposition Analysis: With Application to the Social and Administrative Science. North Holland, Amsterdam and London.

Töngür, U., \& Elveren, A. Y. (2017). The Nexus of Economic Growth, Military Expenditures, and Income Inequality. Quality and Quantity, 51(4), 1821-1842. doi:10.1007/s11135-016-0368-4 
Töngür, U., Hsu, S., \& Elveren, A. Y. (2015). Military Expenditures and Political Regimes: Evidence from Global Data, 1963-2000. Economic Modelling, 44, 68-79. doi:10.1016/j.econmod.2014.10.004

UTIP (University of Texas Inequality Project). (2018). . http://utip.lbj .utexas.edu/.

Vasudevan, R. (2016). Financialization, Distribution and Accumulation: A Circuit of Capital Model with A Managerial Class. Metroeconomica, 67(2), 397-428. doi:10.1111/meca.12106

Weisskopf, T. (1976). Theories of American Imperialism. In D. Mermelstein (Ed.), Economics: Mainstream Reading and Radical Critiques. Random House, New York.

World Development Indicators. (2017). . http://wdi . worldbank.org/tables.

Zeitlin, M. (1974). On "Military Spending and Economic Stagnation". American Journal of Sociology, 79(6), 1452-1456. doi:10.1086/225710 